\title{
Writing of Contemporary National Literary History in Finland and Hungary - a Comparative Approach
}

\author{
RENÁTA BALÁZS
}

\begin{abstract}
The discourse on the writing of national literary histories is still in progress due to the postcolonial and transnational turn. In the frameworks of these literary theories, the meaning of national has been reshaped by focusing on the territorial, ethnic and language borders of contemporary literature. The theory of literary history writing had to face the issues of defining the phenomenon of migrant, emigrant and minority literature. A new Hungarian book titled Kik vagytok ti? Kötelezö magyar irodalom - Újraélesztö könyv (Who Are You? Compulsory Hungarian Literature - A Revitalizing Book) (2019), also evoked a debate concerning the theoretical issues of Hungarian literary history writing. In this debate, not only the author and his critics confronted but also the critics with one another. By analysing the critiques and the author's answers, the fundamental questions of the national literary history writing can be identified. With this metadiscursive approach, I aim to present the current state of Hungarian national literary history writing focusing on the minority and emigrant literature. I will compare the questions generated by the migrant literature in Finland to the issues emerging in the debate about Hungarian literature. This comparative and metadiscursive approach helps to understand the shaping process of the national literature in the dynamics of canonizations and marginalisation.
\end{abstract}

Keywords: Háy János; national literary history writing; literary critic; emigrant and minority literature in Hungary; migrant literature in Finland

In my doctoral research I investigate the Finnish and Hungarian literary field. In both countries the state of literary histories has been a crucial issue that can be detected in the on-going projects of rewriting the national literary histories. ${ }^{1}$ My focus is on the main works of the national literary histories and the Finnish and Hungarian literature textbooks used in secondary schools. I would like to reveal the strategies which have played a role in constructing contemporary national literary histories by analysing and comparing these theoretical works.

1 The draft of the newest Hungarian literary history is available on the Internet: http:// itk.iti.mta.hu/kecskemeti/bblitems/kg2014c.pdf (07.11.2019). 
First, I will concentrate on a current Hungarian debate on writing literary histories. Secondly, this debate implies the relationship between centre and periphery regarding the status of minority and majority literary cultures. Finally, I will present how the question of minority and majority arises in Finnish literary history writing and how this comparative and metadiscursive approach between Finnish and Hungarian Literature helps to understand the shaping process of national literature in the dynamics of canonizations and marginalisation.

The writing of national literary history has recently been discussed in the frameworks of feminism, postcolonialism, and transnationalism. These literary theories have been challenging the national literary histories by questioning who can become a national writer, in which languages the national literature can be written and if it is still possible to write the history of a national literature. For instance, the phenomenon of migrant literature has led to the rethinking of the national literary frame in Finland (Nissilä 2016). The question of the literary history writing theory has recently been analysed for example by Heidi Grönstrand with her co-authors (2016) in the book From the Shadow of the National. About the Transnationalism of Finnish Literature, as well as in the Hungarian volume of studies called Transculturalism and Bilingualism in the Central-European Literatures edited by Zoltán Németh and Magdalena Roguska (2018).

The terms migrant, minority, multicultural, transnational, and transcultural literature are in strong relation with the national literary field even if they are provoking it. As Mikko Pollari and his co-authors write: "Despite the transnational turn within study of literature, the national still occupies a central role in the way literature is produced and consumed, as well as conceptualized and presented. Therefore, it cannot be left out of the research agenda of literary studies" (Pollari et al. 2015: 13).

\section{A Current Debate on (National) Literary History in Hungary}

Concerning Hungarian literary history and national canon, a new debate emerged in the spring of 2019 when János Háy's new book Who Are You? Compulsory Hungarian Literature - A Revitalizing Book has been published. Its author, János Háy, is well-known and mostly popular for his works of fiction. ${ }^{2}$ The structure of the book consists of chapters about Hungarian

2 Háy, by his original name János Horváth (1960-) writer, illustrator and publishing house founder is known for his fiction works. His oeuvre consists of poems, short 
BALÁZS

writers, focusing on their lifestyle and the connection between the authors and their works. The texts are close to the essay genre. Soon after publication it turned out to be a highly provocative work. The reviews written mainly by academic researchers and secondary-school teachers outline a discourse on the fundamental questions of contemporary national literary history writing. My aim is not to assess Háy's book and thus take part in the debate about the book's values as a literary history, but to concentrate on the theoretical aspects of the current Hungarian literary history writing by analysing this debate.

According to the blurb written by the publisher, the book may be read as a literary history, even Antal Szerb is mentioned as a parallel, who also wrote a popular literary history at the beginning of the $20^{\text {th }}$ century (Szerb 1935). But first, it is an exciting Háy-fiction, which aims to make the dusty compulsory writers popular again. The original aim of this blurb was presumably to promote the book, but in the end (with a little exaggeration) it started a war culminating in the sentence by one of the critics: "It is the biggest disaster which could happen to the Hungarian literary history" (Melhardt 2019).

In Hungary, there is already a "tradition" of literary histories with single authors, just like Háy and Szerb. Lajos Grendel's work (2010) about modern Hungarian literature got an overall positive review and critics appreciated the way he handled the results of literary studies in his work (Olasz 2011). An interesting example is the anthology Három veréb hat szemmel (1977) by one of the best-known Hungarian poets, Sándor Weöres, which presents a personal alternative canon of Hungarian poems, putting formerly unknown and women writers forward. Nevertheless, the book is not an ordinary literary history but a provocative work because Weöres consciously wanted to influence the canon of Hungarian poems and he tried to renew it (Selyem 2008). The last extensive literary history was published more than fifty years ago (Sötér 1964-1966) and despite the fact that the most recent, albeit less comprehensive one - written by university teachers - came out in 2010 (Gintli 2010), there is still a constant demand for a new literary history. Therefore, the promotion of Háy's book as a literary history was a successful marketing concept.

stories and dramas. His first volume of poetry Gyalog megyek hozzád sétálóuton (Walk Towards You on The Footpath) was published in 1989. Since then, he has published two novels, Dzsigerdilen (1996) and Xanadu (1996) and a play Géza gyerek (Child Géza) (2001). The latter was translated into Estonian under the title Géza-poisike in 2008 . He is one of the most awarded contemporary Hungarian writers. Háy is reckoned among the reformers of Hungarian modernist literature because of his self-reflective nonlinear storytelling and the playfulness of the usage of literary language. (Valuska 2004). 
Writing of Contemporary National Literary History in Finland and Hungary

The book had an impressive initial reception. It has won a prize at the International Book Festival in Budapest for helping and supporting education not only by its content but also by its outstanding appearance. The committee members were teachers in a Hungarian secondary school.

Two months after publication two critiques appeared in the same cultural and literature magazine. Balázs Füzfa, who himself has been an editor of a literature textbook series, gives a quite positive review about the book (Füzfa 2019). In his opinion, the work is an unusual literary history, which is able to vivify the textbooks' boring figures and thus helps the students to get closer to the great classics. Even though Füzfa admits that there are disproportionalities in the book - namely that some authors get twice as much place as others, or some canonized writers are missing, whereas other, less-known authors are presented - he does not consider these to be problematic.

On the contrary, the other critic and literary historian, István Margócsy, ${ }^{3}$ writes about the book in a vitriolic style, and also remarkably shortly which indicates that he wants to extenuate the importance of the work. He outlines that the book represents itself as if it were the first literary history that can say something new and it does not take into account the past two hundred years' tradition of literary history writing - not to mention its factual errors (Margócsy 2019).

The harshest critic, Gergő Melhardt analyses the book systematically from the aspect of the theory of literary history writing. In his opinion, the book does not meet the academic requirements at all. For example, it lacks the whole academic reference system. Besides the formal criteria, the work does not problematise the question of language, meaning that in János Háy’s book Hungarian literature is written by Hungarian authors living in Hungary and using Hungarian as their working language. Not a single emigrant author publishing in a different language is presented, nor are any of those writers considered or theorised who remained beyond the borders of Hungary after the First World War. Furthermore, Melhardt highlights, that Háy's concept does not seem to recognise the contributions of the feminist researchers, which can be noticed in the way he describes female writers, if they are mentioned at all (Melhardt 2019).

The next debater, László Arató is a secondary school teacher and the chairman of the Hungarian Literature Teachers' Association. The organisation's

István Margócsy is a former head of Department of Classical Hungarian Literature at Eötvös Loránd University in Budapest. He is awarded and recognized not just as a critique, but also for his works on the field of literary history. 
main activity is to help secondary school teachers in numerous ways, for instance by analysing compulsory works, or by organizing courses about teaching methods of Hungarian literature. Unlike the others, who have published their opinions in literary magazines, he posted his opinion on his personal Facebook page, however, signing it as the chairman of the abovementioned association. His main concern was, that by using Háy's book as a handbook, the improvements in literary education will be endangered because literary works should be approached and analysed through their inner characteristics and not through the authors' lives as it was formerly the case and as Háy still does (Arató 2019).

The whole issue may have fallen into oblivion, if a popular weekly newspaper, the $H V G$ had not picked up Arató's Facebook post. The newspaper presented and assessed his comment as if it had been a personal attack against the writer of the book (22.07.2019). Háy replied to the newspaper's article and mentioned that the critics reminded him of the old communist times when writers were told what and how they should write. He tried to be literary historically correct in his book, but all in all it was his personal (fictional) prose whose protagonists are his colleagues - Hungarian writers, past and present (23.07.2019). However, in the communist era, Háy would not even have had the possibility to reply to Arató's post. He could answer to Arató, because the newspaper offered him the place, but so doing he did not recognise that Arató published his opinion on a non-official site, on his personal Facebook page. The two harshest critics, Melhardt and Arató, were presented as the book's persecutors, therefore they were reluctant to continue the debate in such an atmosphere.

A month later an overview of the debate was published in a literary magazine. Tibor Bárány analysed it from the aspect of the relationship between power and critique. According to him, one of the main problems was that Háy did not place himself into the literary history discourse, however, willingly or not, by writing his book he became a participant in it. The debate indicated another problem as well, concerning online media. Even if each review had been published online, and had therefore been easily available to everyone, the dialogue between the traditional cultural magazines and the political-social weekly failed. The professional literary debate became power politics and an institutional attack of Arató (Bárány 2019).

Finally, another review was published also in August, after Bárány's overview, and added an entirely new angle to the debate, namely the minority issue of the Hungarian literature. Gyöngyi Orbán's main statement was that the starting point of the debate was doomed to failure because it was based on the 
approach that Háy's book was a literary history (Orbán 2019). According to her, the book is actually a belletristic work, which means that we cannot expect the conventions of the literary history writing from the book. Orbán's arguments that Orbán lists in her article are worth considering, and the issue is still open, which is illustrated by one of my personal experiences: when I was looking for the book in a prestigious bookstore, the shop assistant was not sure whether its right place would be on the fiction shelf or literary theory.

\section{The Mechanism of (Self-)inclusion and Exclusion}

Next, I would like to concentrate on another aspect of Orbán's addition to the discourse. Besides the question of literary history writing she (indirectly) expands the debate with the question of excluding or including minority literature. She defines herself as a reader who does not want to take part in the debate, just wants to add a comment from the periphery, because she is afraid of being neglected. Reading the first paragraph of her article a question arose in me: what does this periphery refer to and where can it be? And if there is a periphery, there should be a centre too. But where is this particular centre?

The most obvious answer is that Orbán refers to the historical condition that after the First World War Hungary fell apart and the Hungarian literary field got divided into two main parts: one inside the borders and one outside the borders. Nowadays literature written in Hungarian is published over the borders on the territory of Romania, Slovakia, Serbia, and Ukraine, as well. The status of these literatures has constantly been part of the discussion about Hungarian literature. The dynamic between the centre and the periphery raises questions relating to the level of self-dependence of these literary cultures. Issues related to the literary history status of cross-border literatures are still under discussion. For instance, it is not determined yet whether an individual phenomenon such as Slovakian Hungarian literature exists (Németh 2016) or whether literature inside Romania written in Hungarian should be called Romanian Hungarian literature or Transylvanian Hungarian literature (Balázs 2015).

After the territorial division of Hungary due to the Treaty of Trianon, Budapest functioned as the centre. However, over the last hundred years the relationship between the minority and the majority literature has changed considreably. Melinda Szarvas, a literary critic, has compared this relationship with the notion of cultural gravitation (Szarvas 2018). She says that balancing between the two major cultures (for example the Hungarian and the Romanian) is inevitable in order to maintain the continuity of the minority 
literature culture. According to this cultural model, the independence and the special characteristics of the minority cultures inside the major ones are more important than their dependency on the mother country. The centre and the periphery are in motion: for example, when the communist era was much stricter in Hungary than in the former Yugoslavia, a Hungarian literary magazine (Új Symposion) published in Yugoslavia gained the central role instead of those being published in Hungary, because the western theoretical works - which could not be obtained in Hungary - were published in Yugoslavia in Hungarian.

Orbán's article has appeared in an independent Transylvanian online literary magazine, which publishes cultural and political writings as well. The magazine was founded four years ago as an anti-mainstream literary magazine. Nowadays it has quite a high prestige: recognized literary critics and fiction writers can be found among its authors, and the magazine's editors have got a prize from one of the most illustrious literary magazines last year.

Indeed, it is true, that apart from Orbán, all the other four critics of the books are Hungarian citizens. But, for instance, Tibor Bárány's overview of the debate has been published in Korunk, which is one of the most recognized Transylvanian literary magazines. Sooner or later, all the reviews are going to be published on the internet, and in my opinion, we cannot pose a hierarchy among critics in this debate. The Transylvanian critic, who is a recognized university teacher as well, should not be afraid of being neglected because she writes from the so-called periphery. The field of the Hungarian literary criticism is not homogeneous at all, but nowadays cross-border researchers with relevant results can be as recognized as those who are working in Hungary. I believe the minority status has no place as an excuse in this professional debate, because it is ineffective, and this self-exclusion weakens the productivity of the minority discourse. There are also efforts to connect the different parts of the Hungarian literary field: for example, the Litera is located in Budapest and has a remarkably central position, nonetheless it offers opportunities for dialogue among the representatives of the other cross-border literatures. For instance, its Kilátó (Watchtower) ${ }^{4}$ project successfully collects and presents physically isolated literary fields through a mutual online forum by publishing works from the cross-border Hungarian-inhabited territories.

Henceforth, the question that Orbán indirectly raises, namely the exclusion or inclusion of minority literature is also relevant, and it is worth analysing how it is presented in the literary history theory. For instance, a new literary

4 The project can be followed here: https://litera.hu/dosszie/kilato-hataron-tuli-irodalmi-szemle.html (20.01.2020). 
history project is in progress in Hungary. The draft of the book is available from 2014. It was very thought-provoking to read the part concerning the literature of emigration. Especially after the Hungarian revolution in 1956, a lot of Hungarian writers have moved abroad and published literary works either in their mother tongue or in the language of that particular country. These works have raised a question about the essence of Hungarian literature: in what languages can it be written? The author of the draft, Gábor Kecskeméti, outlines that the importance of the problem is considered nowadays, but it will be difficult to give the emigrant writers the rightful place in the future literary history because of the lack of the relevant studies (Kecskeméti 2014: 782).

Five years later Gábor Schein analyses the notion of emigrant literature in his article, and his main concern is that the Hungarian literary history has not been able to deal with the experiences of the migration (Schein 2019). Because of the complexity of the topic I cannot present the whole article, but I would like to highlight the observations which concern my topic. After the Hungarian Revolution of 1956, the Hungarian literary history denied the existence of emigrant writers for political reasons. When they rarely appeared in the literary histories, they were mentioned as western writers, which was a euphemism. Even as late as 2007, authors who had written in languages other than Hungarian could be just the appendixes of the then published literary history. However, according to Schein, as literary historians, we must ask again and again: what is Hungarian in Hungarian literature? (Schein 2019: 8). It must be remembered that the paradigm of monolingualism was born in the $19^{\text {th }}$ century with the nation-states. Transnational studies can show how the fear of losing national homogeneity can be turned into a positive opportunity of diversity.

\section{The Minority Aspect in Finland - the Use of a Comparative Approach}

From this aspect comparative literature has a crucial role even today. It can show how other literary cultures have been dealing with the same or similar issues. As I mentioned at the beginning of my article, I aim to investigate the Hungarian and the Finnish literary field. ${ }^{5}$ Especially during the last few years

5 I have analysed Alexandra Salmela's works from the aspect of narratology in my master's thesis Az idegenség narratívái. 'The narratives of alienage' (2018). I pointed out how Salmela constructs the immigrant as an alien through language and narratee and hereby her works cannot be read simply as mirrors of migration. 
BALÁZS

Finnish literature has been challenged by writers with migrant backgrounds. One of these writers is the Slovakian Alexandra Salmela, who became famous for her first novel, which has been written in Finnish. When the book was shortlisted for the Finlandia Prize - the greatest Finnish literature award -, it turned out, that it was not eligible for winning it, because Salmela was not a Finnish citizen. The Finnish committee finally decided to change the rules during the contest, thus every work since 2010, written either in Finnish or Swedish (the official language of Finland as well) can get the prize regardless of the author's citizenship. This change means a turning point in the Finnish literary history writing (Nissilä 2016: 156-157). However, the roots of the migrant writers' date back to the 1990s, when many writers with migrant background started to publish in Finland. The discourse about who can become a Finnish writer has pointed out the literary position of the other minorities such as Sami, Swedish-Finnish and Romani. (Nissilä - Rantonen 2013: 55). The Contemporary Finnish Literary History (Hallila et al. 2013) has already problematised and analysed the question of migrant literature in a whole chapter. One of the cornerstones of the theoretical debate was the categorisation and the denomination of the phenomenon. It would be another article's topic to present the history of the notions of multicultural literature (monikulttuurinen kirjallisuus), migrant literature (maahanmuuttajakirjallisuus), newfinnish literature (uussuomalainen kirjallisuus) and literature over borders (ylirajainen kirjallisuus).

In conclusion, the Finnish literary history writing seems to be more open and adaptable to the new challenges. The migrant literature in Finland and the Hungarian emigrant literature deserve to be compared even if they have significant cultural-literary differences. Transnational studies of the national literatures can add new perspectives to the national self-understanding and reveal the similar issues, hence the possible problem-solving methods of the particularities.

\author{
Renáta Balázs \\ reni9424@gmail.com \\ Eötvös Loránd Tudományegyetemen \\ 1088 Budapest, Múzeum körút 4/I \\ MAGYARORSZÁG / HUNGARY
}


Writing of Contemporary National Literary History in Finland and Hungary

\section{References}

A szerző megregulázása egy ócska kor emlékét idézi. 2019. - HVG, 23.07, https:// hvg.hu/kultura/20190723_Hay_Janos_A_szerzo_megregulazasa_egy_ ocska_kor_emleket_idezi (07.11.2019).

Arató, L. 2019. Fogyasztóvédelem. Facebook. 22.07.

Balázs, I. J. 2015. Szótáralapítás egy erdélyi magyar irodalomtörténet megírásához Serestély Zalán ed., Erdélyi magyar irodalom-olvasatok. Kolozsvár: Egyetemi Mühely Kiadó, 7-20.

Balázs, R. 2018. Az idegenség narratívái Alexandra Salmela müveiben. Master's thesis. Manuscript. Budapest: ELTE BTK Magyar Irodalom- és Kultúratudományi Intézet.

Bárány, T. 2019. Az élesztőaffér. Vázlat kritika és hatalom viszonyáról. - Korunk, III/9, 26-37.

Füzfa, B. 2019. Egyszemélyes popzenekarok? - Élet és Irodalom, LXIII/22, https:// www.es.hu/cikk/2019-05-31/fuzfa-balazs/egyszemelyes-popzenekarok.html (07.11.2019).

Gintli, T., ed. 2010. Magyar irodalom. Budapest: Akadémiai.

Grönstrand, H., Kauranen, R., Löytty, O., Melkas, K., Nissilä, H.-L., Pollari, M. 2016. Kansallisen katveesta. Suomen kirjallisuuden ylirajaisuudesta. Helsinki: SKS.

Hallila, M., Hosiaisloma, Y., Karkulehto, S., Kirstinä, L., Ojajärvi, J., eds. 2013. Suomen nykykirjallisuus 1-2. Helsinki: SKS.

Háy, J. 2019. Kik vagytok ti? Kötelező magyar irodalom. Budapest, Európa Könyvkiadó.

Kecskeméti, G. 2014: Az MTA BTK Irodalomtudományi Intézetében elkészítendő magyar irodalomtörténet megalapozása. - Irodalomtudományi Közlemények, 6, 747-783.

Lajos, G. 2010. A modern magyar irodalom története - Magyar líra és epika a 20. században. Pozsony: Kalligram.

Margócsy, I. 2019. Kisebbségben. - Élet és irodalom, LXIII/22, https://www.es.hu/ cikk/2019-05-31/margocsy-istvan/kisebbsegben.html (07.11.2019).

Melhardt, G. 2019. Ellenpélda. - Litera, 20. 07, https://itera.hu/irodalom/ konyvajanlo/melhardt-gergo-ellenpelda.html (07.11.2019).

Nekiment a Magyartanárok Egyesületének Elnöke Háy Jánosnak. 2019. - HVG, 22.07. https://hvg.hu/kultura/20190722_Hay_Janos_Arato_Laszlo_Magyartanarok_ Egyesulete_Kik_vagytok_ti?fbclid=IwAR1RMZZbtTlmv0pxRy0Nw8B4laBUzM0wbu8J2hoI8o-et5tM8CnQXP0jA8 (07.11.2019).

Németh, Z. 2016. A migráns irodalom lehetőségei a közép-európai irodalmakban. Iskolakultúra, 1, 63-69. https://doi.org/10.17543/ISKKULT.2016.1.63

Németh, Z., Roguska, M., eds. 2018. Transculturalism and Bilingualism in the CentralEuropean Literatures. Nitra: Közép-európai Tanulmányok Kara.

Nissilä, H.-L. 2016. Vuotoja kansallisessa säiliössä. Muistiinpanoja tutkimusmatkaltani ylirajaiseen kirjallisuustutkimukseen. - H. Grönstrand et al., Kansallisen katveesta. Suomen kirjallisuuden ylirajaisuudesta. Helsinki: Suomen Kirjallisuuden Seura. 
BALÁZS

Olasz, S. 2011. „Mit akar ez az egy ember”. - Jelenkor, 1, 85-90.

Orbán, G. 2019. Ellenpéldák (mi mire/minek?). Olvasói közbeszólás a peremről. A Szem. http://aszem.info/2019/08/ellenpeldak-mi-mire-minek-olvasoikozbeszolas-a-peremrol/ (07.11.2019).

Pollari et al. 2015. National, Transnational and Entangled Literatures: Methodological Considerations Focusing on the Case of Finland. - A.-S. Lönngren, ed., Rethinking National Literatures and the Literary Canon in Scandinavia. Newcastle upon Tyne: Cambridge Scholars Publishing, 2-30.

Schein, G. 2019. Az emigráció mint a magyar irodalomtörténeti gondolkodás szerkezeti problémája. - Irodalomtörténet, 1, 3-17.

Selyem, Z. 2008. Posztkom magyar és román nőirodalom. - Lettre, 71, http://www. epa.hu/00000/00012/00055/selyem.htm (16.01.2020.)

Sőtér, I., ed. 1964-1966. A magyar irodalm története I-VI. Budapest: Akadémiai.

Szarvas, M. 2018. Tükörterem flamingóknak. Irodalomtörténeti tanulmányok a magyar vajdasági irodalomról. Budapest: FISZ.

Szerb, A. 1935. Magyar irodalomtörténet. Budapest: Révai.

Valuska, L. 2004. Háy János. - Szépirodalmi figyelő, 4, 110-116.

Weöres, S. 1977. Három veréb hat szemmel. Budapest: Szépirodalmi. 